\title{
Laminate Device
}

National Cancer Institute

\section{Source}

National Cancer Institute. Laminate Device. NCI Thesaurus. Code C50024.

A material consisting of multiple layers bonded together. 